\title{
A new triaxial apparatus for testing soil water retention curves of unsaturated soils under different temperatures*
}

\author{
Guo-qing CAI ${ }^{\dagger}$, Cheng-gang ZHAO, Jian LI, Yan LIU \\ (Department of Geotechnical and Geoenvironmental Engineering, School of Civil Engineering, Beijing Jiaotong University, \\ Beijing 100044, China) \\ †E-mail: guoqing.cai@bjtu.edu.cn \\ Received Nov. 4, 2013; Revision accepted Apr. 9, 2014; Crosschecked Apr. 25, 2014
}

\begin{abstract}
This paper presents a new triaxial apparatus for testing soil water retention curves (SWRCs) under different temperatures. The components of this modified apparatus, as well as the special features of each component, were described. The key part of this innovative apparatus was the temperature control system, which was cooperated with a loading system and a suction control system. Different methods of heating were compared and a more effective method, which used a heating element around the pressure chamber, was consequently adopted. Under different temperatures $\left(25,40\right.$, and $\left.60^{\circ} \mathrm{C}\right)$ and different net mean stresses $(40$, 100 , and $200 \mathrm{kPa}$ ), typical results from the SWRCs tests for unsaturated silty clay were presented and analyzed. The experimental results show that the volumetric water content reduces with the increasing temperature at constant suction.
\end{abstract}

Key words: Unsaturated soils, Temperature controlled, Triaxial apparatus, Volume change, Soil-water characteristic curve doi: 10.1631 jzus.A1300358

Document code: A

CLC number: TU411.4

\section{Introduction}

There are numerous geotechnical engineering problems in which temperature effects are significant and non-isothermal conditions must be considered, such as landfill engineering, hydrocarbon recovery in oil sands and from oil reservoirs, pipeline engineering, geothermal energy development, drainage enhancement, pavement engineering, and buried power cables (Gens, 2010). Previous studies on the basic properties of unsaturated soils, referring to either constitutive models or laboratory experiments, are mostly conducted at room temperature, ignoring the potential temperature effect (Alonso et al., 1990; Sivakumar and Wheeler, 2000; Wheeler et al., 2003; Cunningham et al., 2003; Sun et al., 2007; Sheng et al., 2008). However, soils are always in their natural

\footnotetext{
* Project supported by the National Natural Science Foundation of China (Nos. 51208031 and 51278047), and the National Basic Research Program (973) of China (No. 2010CB732100)

(C) Zhejiang University and Springer-Verlag Berlin Heidelberg 2014
}

environment, whose properties change with moisture content and temperature. Ignoring the impact of environment factors would lead to inaccurate evaluation of the hydro-mechanical properties of soils, and to the inability to meet the actual needs of practical projects (Gens, 2010). Owing to recent developments in permafrost engineering, achievements have been obtained from the studies of the effect of low temperatures on soil properties. In contrast, research on the effect of high temperatures on soil properties is developing relatively slowly. Recently, with the development of modern geotechnical engineering practices, studies that consider the effect of high temperatures on the basic properties of unsaturated soils have attracted more attention. In the high-level radioactive waste repository, unsaturated bentonite, an important engineered barrier, has been utilized as a buffer/backfill material. When subjected to nuclear waste heat, the temperature of the soil changes, affecting the water-holding capacity of the soil and causing flow and deformation. As a result, new features are produced, which are different from those of 
soils at room temperature. In numerous engineering construction practices, such as exploitation and utilization of geothermal resources, $\mathrm{CO}_{2}$ underground storage, high-voltage cable burial, and petroleum exploitation, the studies on the effect of temperature, specifically high temperature, on the hydromechanical properties of unsaturated soils have important theoretical significance and application value.

A number of constitutive models and experimental studies have been developed to analyze the behavior of saturated soils under different temperatures (Hueckel and Borsetto, 1990a; Delage et al., 2000; Cui et al., 2000; Laloui and Cekerevac, 2003; Zhou and Yu, 2005; Yao and Zhou, 2013). However, the models that consider the temperature effects on unsaturated soils are limited (Francois and Laloui, 2008; Tang and Cui, 2009; Cai et al., 2010; 2011; Zhou et al., 2014).

As there is no temperature control and measurement system included, the normal test system cannot meet the requirements to study the temperature effect on the basic properties of soils. Thus, a temperature-controlled apparatus is indispensable. However, the majority of experimental research focus on the temperature effect on the behavior of saturated soils, as exemplified by Campanella and Mitchell (1968), Hueckel and Baldi (1990b), Towhata et al. (1993), Delage et al. (2000), and Abuel-Naga et al. (2007).

Experimental studies of the temperature effect on the mechanical and hydraulic properties of unsaturated soils have been scarce, particularly studies that focus on temperatures higher than those occurring in nature (i.e., geothermal, nuclear waste disposal). In the limited literature on this topic, temperature-controlled oedometers, isotropic and triaxial apparatuses were developed and used. In the first reported systematic study on temperaturecontrolled tests on unsaturated soils, Romero et al. (2003) presented experimental results about the suction and temperature effects on the volumetric behavior of compacted Boom clay. In this study, a temperature-controlled oedometer apparatus placed inside a thermostatic silicone oil bath was used. By putting the oedometer in a thermostatic water bath, Villar and Lloret (2004) obtained the results on the influence of temperatures (between $20^{\circ} \mathrm{C}$ and $80^{\circ} \mathrm{C}$ ) on the hydro-mechanical properties of compacted
FEBEX bentonite. Francois and Laloui (2010) developed an advanced thermo-hydro-mechanical oedometer. Water retention data and compression curves under different suctions and temperatures were obtained. Tang et al. (2007; 2008) developed a new suction and temperature-controlled isotropic cell, which was immersed in a temperature-controlled water bath to study the thermo-mechanical behavior of compacted MX-80 bentonite. By modifying the temperature control of the Bishop-Wesley triaxial apparatus through a heating element and a sensor located at the bottom of the triaxial cell, Uchaipichat and Khalili (2009; 2011) developed a temperaturecontrolled triaxial apparatus for testing unsaturated soils at elevated temperatures up to $60^{\circ} \mathrm{C}$. Moreover, the experimental investigation of thermo-hydromechanical behavior of unsaturated silt was presented in their study.

The laboratory experiments on the mechanical and hydraulic properties of unsaturated soils under different temperatures enabled the isolation of different coupling processes, and facilitated the interpretation of thermo-hydro-mechanical coupling behavior. During these experimental processes, choosing an effective method for controlling suction and temperature is necessary. Three main techniques are generally used to control the suction within a soil sample: axis translation technique, osmotic technique, and relative humidity technique. Several different methods are also used to control temperature, which include directly heating the water in the pressure chamber by a heater, heating the water by heating coils placed around the pressure chamber, placing the experimental system in a temperature-controlled laboratory, and placing the pressure chamber in a temperature-controlled bath with oil or water. The first method is the easiest one to be applied and the most widely used. However, one of the greatest limitations of this method is the difficulty in evenly heating the water in the pressure chamber by the heating rod or spiral copper tube. To overcome this difficulty, researchers install an electric propeller in the pressure chamber to stir the water during heating. The propeller balances the temperature of the water in different locations. Ultimately, the temperatures of the soil sample at different parts are consistent (Uchaipichat and Khalili, 2009; Uchaipichat et al., 2011). However, the installation of an electric 
propeller will create another problem. The disturbance of the water flow produces unpredictable effects on various kinds of lines and sensors. The third method does not require the installation of any heating device in the experimental setup, which undoubtedly reduces the difficulty in instrument development. However, the construction cost for the temperature-controlled laboratory is relatively high, and it is difficult for laboratory technicians to adapt to a high-temperature environment. The fourth method is effective in achieving even heating, but difficulties arise in placing a triaxial apparatus into the bath, relative to the isotropic or oedometric cell. Among these methods, the second method is the most reasonable and economical way of developing a temperature-controlled triaxial apparatus which can be selected and improved.

In this paper, an innovation on the triaxial apparatus for unsaturated soils for testing unsaturated soils under different temperatures is presented. The apparatus is a modified version of a GDS triaxial apparatus. Suction is applied using the axis translation technique. The temperatures of the soil sample and surrounding water are controlled by the ring-type electric heating plates around the pressure chamber. An effective method, which uses a heating element around the pressure chamber, is adopted. The components of this modified apparatus are calibrated, and described together with their special features. The key part of this innovative apparatus is the temperaturecontrolled system, which is co-worked with the loading system and suction control system. By using the modified triaxial apparatus, typical results from the soil water retention curve tests under different temperatures $\left(25,40\right.$, and $\left.60{ }^{\circ} \mathrm{C}\right)$ and different net mean stresses $(40,100$, and $200 \mathrm{kPa})$ of unsaturated silty clay are presented and analyzed.

\section{Experimental setup}

The new apparatus is developed by modifying a triaxial test system for unsaturated soils, to which a temperature control and measurement system has been added. It consists of three parts: the loading system, suction control system, and the temperature control system. In addition, some improvements were made to increase the heating efficiency and reduce undesired temperature effects on the other parts. The schematic diagram of the temperature-controlled triaxial apparatus for unsaturated soils is shown in Fig. 1. Fig. 2 is the basic scheme of the designed temperature-controlled pressure chamber, which is the key part of the apparatus.

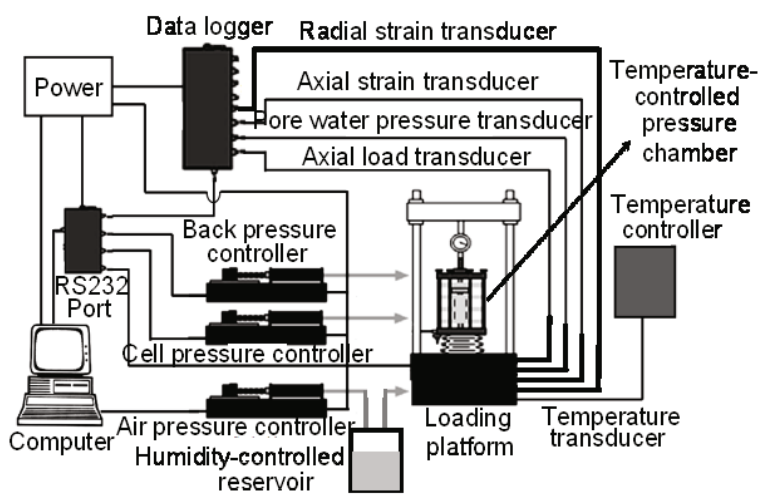

Fig. 1 Schematic diagram of temperature-controlled triaxial test system

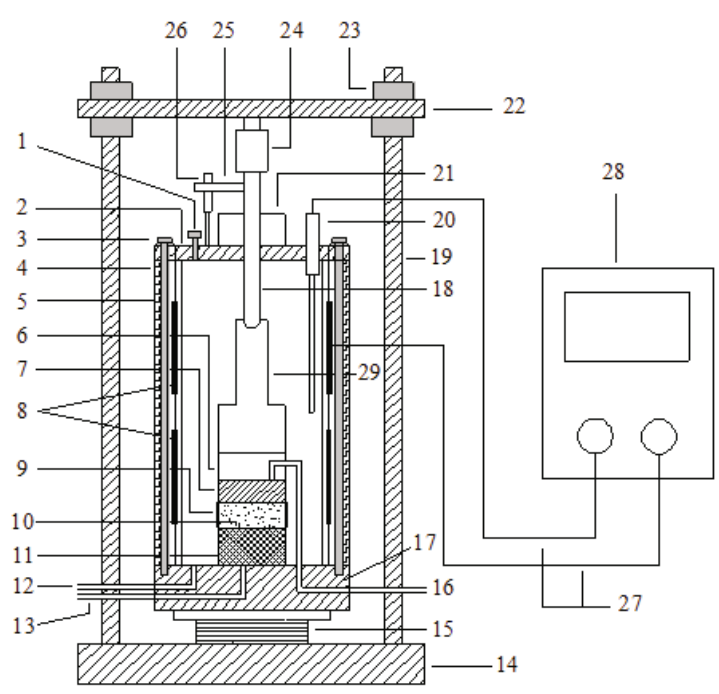

Fig. 2 Schematic diagram of the pressure chamber in the temperature-controlled triaxial test system for unsaturated soils

1: vent valve; 2 : head cover of the pressure chamber; 3 : fixed screw rod of pressure chamber; 4: stainless steel cylinder; 5: insulating asbestos; 6 : sample cover made of organic glass; 7: porous stone; 8: heater; 9: rubber membrane; 10: soil sample; 11: ceramic plate with high air-entry value; 12: confining pressure imposing and testing tube; 13: counter pressure imposing and testing tube; 14: loading frame bearing platform; 15: lifting platform; 16: air pressure imposing and testing tube; 17: base of pressure chamber; 18: axial piston rod; 19: support bar of loading frame; 20: temperature sensor; 21: piston cover; 22: beam; 23: fixing bolt of loading frame; 24: axial load sensor; 25: bracket; 26: axial displacement sensor; 27: wire; 28: temperature controller; 29: elevated cushion block 


\subsection{Loading system}

The loading system used in this study is based on an isothermal WF loading platform. Three GDS advanced pressure/volume controllers are connected to the basement for controlling the stress state. The GDS advanced pressure/volume controller (ADVDPC) is a commercial general-purpose water pressure source and volume change gauge for the precise regulation and measurement of fluid pressure and volume change. A data acquisition instrument is also connected between the transducers and a computer for automatic data logging and processing. The axial load is applied by a lifting platform beneath the pressure chamber and measured by a load cell above the chamber. The axial deformation is measured by a LVDT transducer in contact with the top of the chamber, which is fixed on a loading piston. The cell pressure is applied by a GDS water filled controller with the maximum value of $1 \mathrm{MPa}$. To prevent heat losses, the cell is designed to include a double stainless steel wall with heaters inside. With the loading system, soil water retention curves (SWRCs) under different isotropic stresses can be tested, which makes it possible to study the stress level effect on the SWRC.

\subsection{Suction control system}

The axis translation technique has been chosen for suction control within the suction levels up to several hundred $\mathrm{kPa}$. This is achieved by placing a high air entry ceramic disk between the pedestal and the base of the soil sample. The basic principle of the axis-translation technique is to elevate pore air pressure, $u_{\mathrm{a}}$, to increase pore water pressure, $u_{\mathrm{w}}$, to be positive, and to prevent cavitations in the water drainage system. Total stress $\sigma$ is increased with air pressure $u_{\mathrm{a}}$ at the same amount to remain net stress $\left(\sigma-u_{\mathrm{a}}\right)$ unchanged. This process is referred to as 'axistranslation'. Axis-translation is accomplished by separating air and water phases in the soil through porous material with a high air entry value $(\mathrm{AEV})$. A ceramic disk can maintain continuous flow of the pore water, but prevents the passage of air. However, the separation of the water and air can be only realized on the condition that the suction of the soil sample is smaller than the AEV of the ceramic disk. A ceramic disk with high AEV of $500 \mathrm{kPa}$ is used here. As shown in Fig. 2, the soil sample is sandwiched be- tween the ceramic disk and porous stone. The pore water pressure is applied by a GDS water filled controller connected to the base of the high air entry disk, while the pore air pressure is applied by another compressed air filled controller via a top cap that ends in the porous stone which is in contact with the top surface of the soil sample. Two holes are drilled in the top cap to allow for the high pressure air flow to the sample.

When the suction changes, the pore water volume change is measured from the flow of water in or out of the sample by the pore water pressure controller. A copper tube is used here for water flow to avoid thermal expansion. To limit the loss of pore water evaporation at high temperatures, a special reservoir has been installed in the air pressure line to humidify the dry air before it reaches the sample. The humiditycontrolled reservoir is partly filled with water in an effort to keep the relative humidity of the chamber air at a level closer to the relative humidity of the pore air of the specimen and is maintained at the temperature of the soil sample.

\subsection{Temperature-controlled system}

The temperature-controlled system consists of a chamber with a heater inside its wall, a temperature controller connected to the chamber and a thermocouple immersed in the chamber. Heating of the sample is obtained indirectly by heating the water in the chamber. The outside space of the chamber is a cavity-shaped structure made of stainless steel, with insulating asbestos, a fixed screw rod, and circular electric heating plates successively arranged from outside to inside. Notably, both the cavity-style structure design and the settlement of the insulating asbestos can effectively prevent heat loss in the pressure chamber.

Temperature measurement is made by using a thermocouple placed on the top of the chamber and at a distance of about $10 \mathrm{~cm}$ from the top of the sample. The thermocouple gives the feedback signal about the water temperature in the chamber to an automatic temperature controller with an accuracy of $\pm 0.5^{\circ} \mathrm{C}$. Once the target temperature value has been input, the temperature controller will order the heating plates to be working until the feedback from the thermocouple indicates the target value has been achieved. When the temperature falls as a consequence of an 
unavoidable heat loss, the heater will start to work again. In this way, the temperature is maintained at the required value.

\subsection{Total volume change measurement}

The hydraulic behavior of unsaturated soils is always affected by the mechanical behavior, which is called hydro-mechanical coupling. During drying/ wetting, the total volume of the soil sample will be changed, and has an influence on the water retention curves. The total volume change measurement is calculated, followed by the derivation of water content and saturation at any state during drying/wetting.

Here, $V_{\mathrm{s}}, V_{\mathrm{w}}$, and $V_{\mathrm{a}}$ are the volumes of solid phase, water, and air, $V_{\mathrm{v}}=V_{\mathrm{w}}+V_{\mathrm{a}}$ is the volume of voids, $V=V_{\mathrm{s}}+V_{\mathrm{w}}+V_{\mathrm{a}}$ is the total volume of the soil sample, $\Delta V$ is the total volume change of the soil sample, and $\Delta V_{\mathrm{w}}$ is the volume change of the water. The solid phase is assumed to be incompressible, so $V_{\mathrm{s}}$ is constant during drying/wetting, while $V_{\mathrm{w}}$ and $V_{\mathrm{a}}$ change with the water flow and volume change.

Thus, the volumetric water content and degree of saturation during drying/wetting are defined respectively as

$$
\begin{gathered}
\theta_{i}=\frac{V_{\mathrm{w} 0}-\Delta V_{\mathrm{w}}}{V_{0}-\Delta V}, \\
S_{\mathrm{ri} i}=\frac{V_{\mathrm{w} 0}-\Delta V_{\mathrm{w}}}{V_{\mathrm{v} 0}-\Delta V},
\end{gathered}
$$

where the subscripts 0 and $i$ represent the initial state and any state during drying/wetting, respectively.

It obviously shows that the water content and degree of saturation change not only with the volume change of water but also the total volume change of the soil sample. As mentioned above, the water volume change can be determined by measuring the flow of water in or out of the sample using the GDS water filled controller. Based on the triaxial apparatus used here, the vertical and radial deformation should be measured respectively for total volume change determination. The vertical deformations can be easily measured by an LVDT transducer which is located on the top of the cell. However, the direct measurement of radial deformation is much more difficult as the transducer is immersed in the cell water, which will make the measurement be highly sensitive to the temperature changes during testing. Romero (1999) used laser-based electro-optical sensors located outside the cell to detect lateral movements along the sample profile with small target size. Uchaipichat et al. (2011) adopted a digital image-processing technique for measuring the total volume change. Both of the above two methods were used for testing soil columns with height larger than diameter, which was necessary for studying the mechanical behavior of unsaturated soils. However, in this study, we focus on the water retention curves under different temperatures and isotropic stress states. So a soil column with height smaller than diameter (with the diameter of $70 \mathrm{~mm}$ and height of $20 \mathrm{~mm}$ ) is adopted to minimize the total volume change, especially the radial deformation. At the end of each test, the change in the diameter of the sample is measured by a vernier caliper which showed a small deformation of about $1.0 \%$, while the height changed up to $10.0 \%$. Based on these results, it is reasonable to ignore the radial deformation, so the total volume change will be calculated only by the axial deformation which can be logged using the apparatus. As the soil sample height decreases, the time for water flow out of the soil will be reduced when a new suction is applied. So with this improvement, the time for testing soil-water characteristic curves will also be reduced.

\section{Calibration}

\subsection{Calibration of measurement devices}

One of the core problems of the temperaturecontrolled triaxial test system is the calibration required to evaluate the temperature effects on the testing apparatus.

1. Axial load and displacement transducer

The calibration of the axial load and displacement transducer was not affected by temperature because they were installed outside the pressure chamber. The load transducer was calibrated by a force measurement controller, and the displacement transducer was calibrated against a micrometer. Both of the calibration curves were linear.

\section{Pressure transducers}

A digital pressure gauge was used to calibrate the three pressure transducers in the new triaxial apparatus at different temperatures to observe the cell 
pressure, pore water pressure, and pore air pressure transducers. After setting the temperatures at 25,40 , and $60{ }^{\circ} \mathrm{C}$, five different cycles of pressure changes were applied. No obvious changes between the zero value point and the calibration factor were observed.

3. Thermocouple

A thermocouple was used to measure the temperature in the pressure chamber. A Callendar's thermometer was used to calibrate the thermocouple over the temperature range from 25 to $60{ }^{\circ} \mathrm{C}$. The calibration factors were obtained from the numerical readings during the process, which show an accuracy of $0.5^{\circ} \mathrm{C}$.

\subsection{Calibration of the time for thermal equilibrium}

Assessment of the differences and the delays in temperatures between the temperature of the water in pressure chamber and that of the soil sample is necessary. During the calibration process, a pair of thermocouples were installed in the heating water and in the middle of the soil column with compacted silty clay. The temperature was increased from $20{ }^{\circ} \mathrm{C}$ to $60{ }^{\circ} \mathrm{C}$ in increments of $10{ }^{\circ} \mathrm{C}$. The temperature changes in both the sample and water are shown in Fig. 3. The results indicate that a delay of approximately $2 \mathrm{~h}$ occurred until thermal equilibrium was reached for each step. Subsequently, no significant differences between the measured temperatures in the surrounding water and the middle of the sample were observed, also indicating the efficiency of the designed pressure chamber.

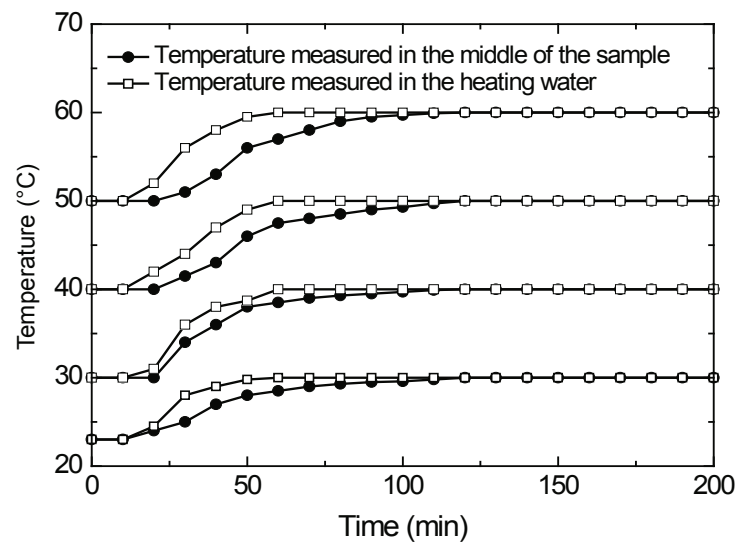

Fig. 3 Temperature changes in the middle of the sample and the heating water versus time during heating (isotropic stress is $500 \mathrm{kPa}$ )

Furthermore, a sufficiently low thermal rating during heating must be applied to avoid undesired pore water pressure generation inside the sample. As pointed out by Francois (2008), this undesired pore water pressure may produce an over consolidated behavior of the sample by decreasing the mean effective stress.

\section{Test material and procedure}

The material used in the experiment is silty clay, obtained from the 7 to $9 \mathrm{~m}$ deep foundation ditch at the station of subway line 8 in Beijing. This type of clay has a liquid limit of $w_{\mathrm{L}}=33.4 \%$, a plastic limit of $w_{\mathrm{P}}=20.1 \%$, and a particle specific density of 2.73 .

The silty clay was compacted into a soil sample with a diameter of $70 \mathrm{~mm}$ and height of $20 \mathrm{~mm}$. The initial moisture content of the sample was $20 \%$ and initial dry density was $1.6 \mathrm{~g} / \mathrm{cm}^{3}$. The soil sample was first saturated by a vacuum extraction followed by adding distilled water in the container. It was proved that after this saturation process, the degree of saturation of the specimen increased to $95 \%$ or more. After the above-mentioned saturation process, the soil sample was wrapped and mounted on the base pedestal of the apparatus. O-rings were then fitted around both the pedestal and the top cap. Then a further saturation was carried out by increasing the back pressure step by step to obtain a "B" value (the ratio of the pore water pressure increment to the cell pressure increment) of 0.96 to ensure a fully saturated specimen.

Both temperature and net mean stress were controlled in the test, to study their effects on SWRC. After the saturation process, an isotropic pressure of $660 \mathrm{kPa}$, air pressure of $460 \mathrm{kPa}$, and back pressure of $455 \mathrm{kPa}$ were imposed. In this case, the samples were loaded to an isotropic net mean stress of $200 \mathrm{kPa}$ to remove the effects of sample disturbance. Next, for different samples, the samples were unloaded to different isotropic net mean stress of 100 and $40 \mathrm{kPa}$ by reducing the isotropic pressure to 560 and $500 \mathrm{kPa}$. After that, the water in the triaxial cell was heated to the desired temperatures $\left(25,40\right.$, and $\left.60{ }^{\circ} \mathrm{C}\right)$ for different samples, and was maintained for $24 \mathrm{~h}$. Then under each isotropic pressure $(500,560$ and $660 \mathrm{kPa})$ and each temperature $\left(25,40\right.$, and $\left.60{ }^{\circ} \mathrm{C}\right)$, the back pressure was reduced to $450,440,410,360,260$, and $160 \mathrm{kPa}$, and the air pressure was kept constant. So 
the matric suction within the sample was increased to $5,10,20,50,100,200$, and $300 \mathrm{kPa}$. The time required to achieve suction equilibrium within the sample was about 4 to $5 \mathrm{~d}$. Nine samples with the same initial void ratio and water content were used for each stress level and temperature. As a result, the SWRCs under different temperatures and isotropic stresses can be obtained. The stress paths in this test are shown in Fig. 4.

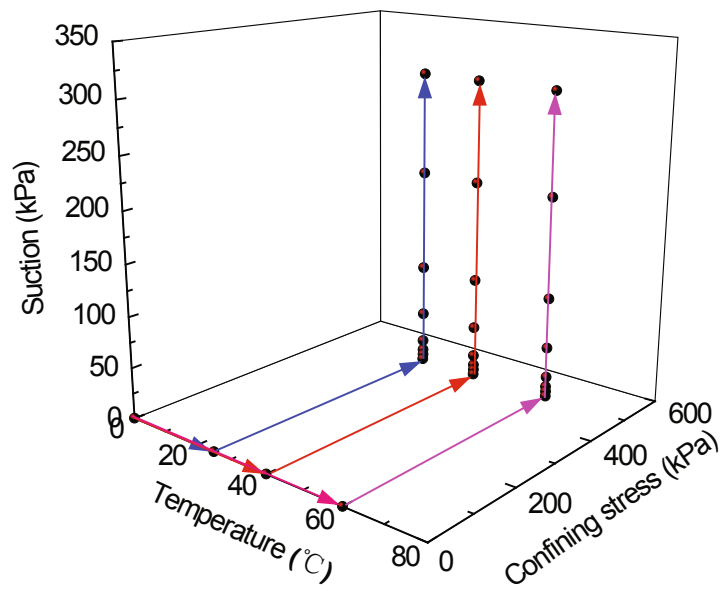

Fig. 4 Stress paths during the test

\section{Results and discussion}

The SWRCs at different temperatures $(25,40$, and $60{ }^{\circ} \mathrm{C}$ ) and certain net mean stress are shown in Fig. 5. In the macroscopic view, the SWRCs move down with the increase of temperature in all of the three net mean stress conditions. This observation indicates that at a constant volumetric water content, the suction is reduced when the temperature increases, whereas the volumetric water content is lower at the higher temperature for a given suction. The temperature increase also leads to the reduction of the AEV of the SWRCs. These observations prove that the increased temperature will generate a decrease in the water retention capability of the soils. This topic was also studied by Romero et al. (2001), Villar and Lloret (2004), Tang and Cui (2005), and Francois (2008) and the same conclusions were drawn based on the results of the heating tests of different types of soils, which used different heating techniques. In addition, the results obtained from the newly developed apparatus are consistent with the predictions of a constitutive model, which was based on thermodynamics (Cai et al., 2010). From these two points of view and following reasonable results, the modified temperaturecontrolled triaxial apparatus has been validated.
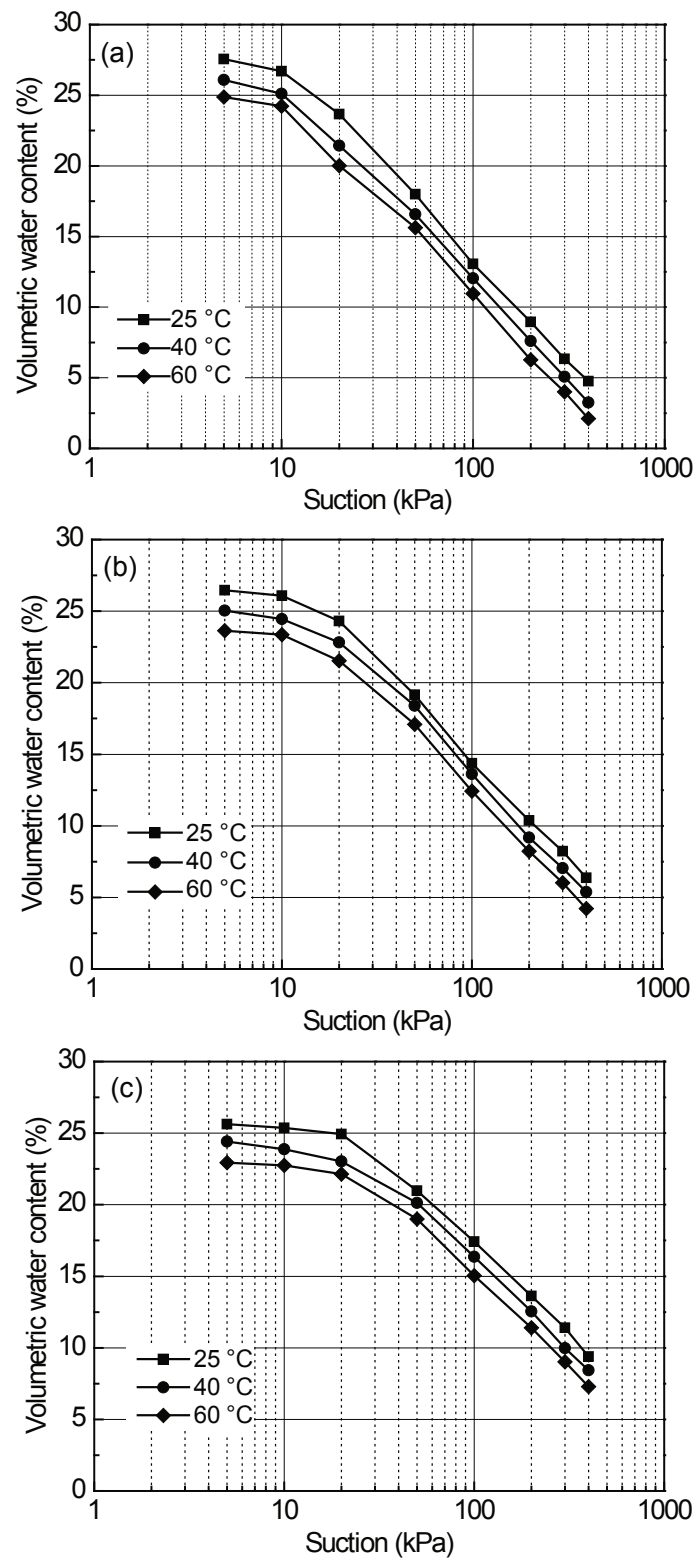

Fig. 5 SWRCs under different temperatures when the net mean stress is $40 \mathrm{kPa}(\mathrm{a}), 100 \mathrm{kPa}(\mathrm{b})$, and $200 \mathrm{kPa}(\mathrm{c})$

Essentially, the decrease in the water retention capability of soils caused by a temperature increase is the consequence of the physical mechanisms that act at different phases and interfaces of the soils. The effect of the temperature on the volumetric friction of each phase in a soil can be categorized into short- and 
long-term effects as dissipative or non-dissipative consequences (Francois, 2008). As a short-term effect, a temperature increase will lead to thermal dilation of different phases and to an increase in the degree of saturation. On the other hand, the solubility of the air in water changes with temperature; the desorbed air from water causes desaturation when the temperature increases. As a long-term effect, surface tension will decrease during heating, which will induce a suction decrease at a constant degree of saturation. In contrast, if the suction is constant, the decrease of the meniscus radius caused by the decrease of the surface tension will lead to drained pores and a decrease of the degree of saturation. Furthermore, the increase of the temperature will generate a decrease in the thickness of the adsorbed water layer, which will also produce a decrease in the degree of saturation.

The SWRCs under the same temperature but different mean stresses are shown in Fig. 6. At the beginning, the SWRCs decrease with the increase of the net mean stress (i.e., the increase of the soil density, or the decrease of the void ratio). That is to say, the amount of water that flows out of the soil sample mainly depends on the net mean stress if the temperature keeps constant. The higher the net mean stress, the lower the void ratio, the steeper the SWRC, and the higher the AEV. This is also consistent with some other model predictions (Gallipoli et al., 2003; Zhou et al., 2012) and other observations (Vanapalli et al., 1999; Romero and Vaunat, 2000; Tarantino, 2009), which also validate the apparatus.

\section{Conclusions}

An innovation on the triaxial apparatus of unsaturated soils for testing SWRCs under different temperatures is presented. The system is an improvement of the existing GDS static triaxial system for unsaturated soils. The temperature control of the soil sample is realized by adding the temperature control system based on a temperature-controlled pressure chamber. The newly developed system can be used to conduct a variety of soil-water characteristic curve testing and static triaxial tests for unsaturated soils at different temperatures. Thus, the system can overcome the shortcomings of the no-temperature change in conventional experiments.
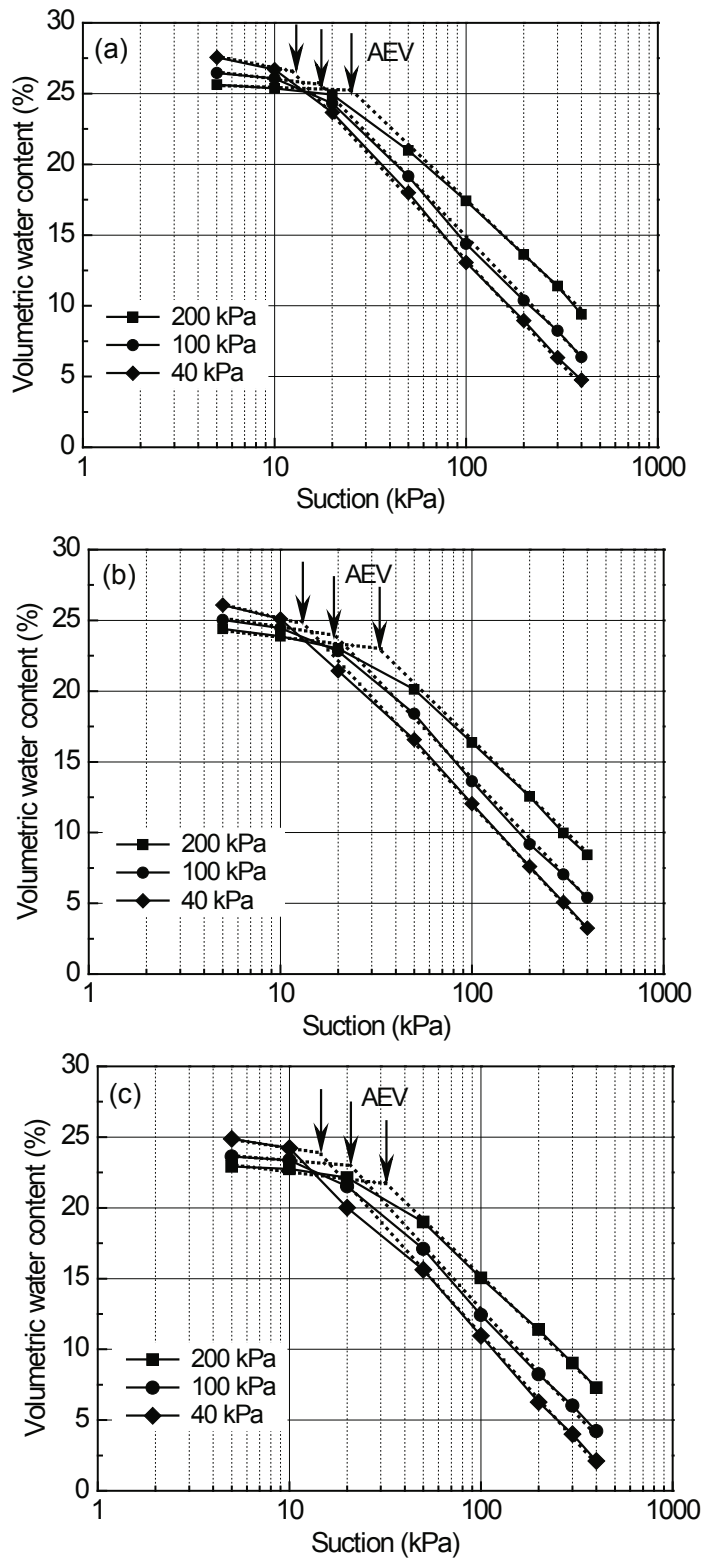

Fig. 6 SWRCs under different net mean stresses when the temperature is $25^{\circ} \mathrm{C}(\mathrm{a}), 40^{\circ} \mathrm{C}(\mathrm{b})$, and $60^{\circ} \mathrm{C}(\mathrm{c})$

The temperature control range of the temperature-controlled pressure chamber was 20 to $80^{\circ} \mathrm{C}$, the confining pressure imposing range was from 0 to $1 \mathrm{MPa}$, and the suction control range was from 0 to $500 \mathrm{kPa}$. Different values can be chosen based on the needs of the actual experiments.

A variety of SWRC tests for unsaturated soils at different temperatures and stress levels have been conducted by using the newly developed temperaturecontrolled triaxial system. The results show that the volumetric water content reduces with the increasing temperature at constant suction, which is consistent 
with both model predictions and observations from other researchers. The experimental results and the calibrations show the effective performance of the developed apparatus.

\section{References}

Abuel-Naga, H.M., Bergado, D.T., Bouzza, A., et al., 2007. Volume change behaviour of saturated clays under drained heating conditions: experimental results and constitutive modeling. Canadian Geotechnical Journal, 44(8):942-956. [doi:10.1139/t07-031]

Alonso, E.E., Gens, A., Josa, A.A, 1990. A constitutive model for partially saturated soils. Géotechnique, 40(3):405430. [doi:10.1680/geot.1990.40.3.405]

Cai, G.Q., Zhao, C.G., Liu, Y., 2010. Temperature effects on soil-water characteristic curve of unsaturated soils. Rock and Soil Mechanics, 31(4):1055-1060 (in Chinese).

Cai, G.Q., Zhao, C.G., Liu, Y., et al., 2011. Volume change behaviour of unsaturated soils under non-isothermal conditions. Chinese Science Bulletin, 56(23):2495-2504. [doi:10.1007/s11434-011-4580-2]

Campanella, R.G., Mitchell, J.K., 1968. Influence of temperature variations on soil behavior. Journal of the Soil Mechanics and Foundations Division, 94(SM3):709-734.

Cui, Y.J., Sultan, N., Delage, P.A., 2000. A thermomechanical model for saturated clays. Canadian Geotechnical Journal, 37(3):607-620. [doi:10.1139/t99-111]

Cunningham, M.R., Ridley, A.M., Dineen, K., et al., 2003. The mechanical behaviour of a reconstituted unsaturated silty clay. Géotechnique, 53(2):183-194. [doi:10.1680/ geot.2003.53.2.183]

Delage, P., Sultan, N., Cui, Y.J., 2000. On the thermal consolidation of Boom Clay. Canadian Geotechnical Journal, 37(2):343-354. [doi:10.1139/t99-105]

Francois, B., 2008. Thermo-plasticity of Fine-grained Soils at Various Saturation States: application to Nuclear Waste Disposal. PhD Thesis, EPFL, Lausanne.

Francois, B., Laloui, L., 2008. ACMEG-TS: A constitutive model for unsaturated soils under non-isothermal conditions. International Journal for Numerical and Analytical Methods in Geomechanics, 32(16):1955-1988. [doi:10. 1002/nag.712]

Francois, B., Laloui, L., 2010. An oedometer for studying combined effects of temperature and suction on soils. Geotechnical Testing Journal, 33(2):112-122. [doi:10. 1520/GTJ102348]

Gallipoli, D., Wheeler, S.J., Karstunen, M., 2003. Modelling the variation of degree of saturation in a deformable unsaturated soils. Géotechnique, 53(1):105-112. [doi:10. 1680/geot.2003.53.1.105]

Gens, A., 2010. Soil-environment interactions in geotechnical engineering. Géotechnique, 60(1):3-74. [doi:10.1680/ geot.9.P.109]

Hueckel, T., Borsetto, M., 1990a. Thermoplasticity of saturated soils and shales: constitutive equations. Journal of
Geotechnical Engineering, 116(12):1765-1777. [doi:10. 1061/(ASCE)0733-9410(1990)116:12(1765)]

Hueckel, T., Baldi, G., 1990b. Thermoplasticity of saturated clays: experimental constitutive study. Journal of $\mathrm{Ge}$ otechnical Engineering, 116(12):1778-1796. [doi:10. 1061/(ASCE)0733-9410(1990)116:12(1778)]

Laloui, L., Cekerevac, C., 2003. Thermo-plasticity of clays: an isotropic yield mechanism. Computers and Geotechnics, 30(8):649-660. [doi:10.1016/j.compgeo.2003.09.001]

Romero, E., 1999. Characterisation and Thermal-hydromechanical Behaviour of Unsaturated Boom Clay: an Experimental Study. PhD Thesis, UPC, Barcelona.

Romero, E., Vaunat, J., 2000. Retention curves of deformable clays. International Workshop on Unsaturated Soils: Experimental Evidence and Theoretical Approaches in Unsaturated Soils, Trento, Italy, p.91-106.

Romero, E., Gens, A., Lloret, A., 2001. Temperature effects on the hydraulic behaviour of an unsaturated clay. Geotechnical and Geological Engineering, 19(3-4):311-332. [doi:10.1023/A:1013133809333]

Romero, E., Gens, A., Lloret, A., 2003. Suction effects on a compacted clay under non-isothermal conditions. Géotechnique, 53(1):65-81. [doi:10.1680/geot.2003.53. 1.65]

Sheng, D.C., Fredlund, D.G., Gens, A., 2008. A new modelling approach for unsaturated soils using independent stress variables. Canadian Geotechnical Journal, 45(4): 511-534. [doi:10.1139/T07-112]

Sivakumar, V., Wheeler, S.J., 2000. Influence of compaction procedure on the mechanical behaviour of an unsaturated compacted clay. Part 1: wetting and isotropic compression. Géotechnique, 50(4):359-368. [doi:10.1680/geot. 2000.50.4.359]

Sun, D.A., Sheng, D., Xu, Y.F., 2007. Collapse behaviour of unsaturated compacted soil with different initial densities. Canadian Geotechnical Journal, 44(6):673-686. [doi:10. 1139/t07-023]

Tang, A.M., Cui, Y.J., 2005. Controlling suction by the vapour equilibrium technique at different temperatures and its application in determining the water retention properties of MX-80 clay. Canadian Geotechnical Journal, 42(1): 287-296. [doi:10.1139/T04-082]

Tang, A.M., Cui, Y.J., 2009. Modelling of thermomechanical volume change behaviour of compacted expansive clays. Géotechnique, 59(3):185-195. [doi:10.1680/geot.2009. 59.3.185]

Tang, A.M., Cui, Y.J., Barnel, N., 2007. A new isotropic cell for studying the thermo-mechanical behavior of unsaturated expansive clays. Geotechnical Testing Journal, 30(5):341-348. [doi:10.1520/GTJ100623]

Tang, A.M., Cui, Y.J., Barnel, N., 2008. Thermomechanical behaviour of a compacted swelling clay. Géotechnique, 58(1):45-54. [doi:10.1680/geot.2008.58.1.45]

Tarantino, A., 2009. A water retention model for deformable soils. Géotechnique, 59(9):751-762. [doi:10.1680/geot.7. 00118] 
Towhata, I., Kuntiwattanakul, P., Seko, I., et al., 1993. Volume change of clays induced by heating as observed in consolidation tests. Soils and Foundations, 33(4):170-183. [doi:10.3208/sandf1972.33.4_170]

Uchaipichat, A., Khalili, N., 2009. Experimental investigation of thermo-hydro-mechanical behaviour of an unsaturated silt. Géotechnique, 59(4):339-353. [doi:10.1680/geot. 2009.59.4.339]

Uchaipichat, A., Khalili N., Zargarbashi, S., 2011. A temperature controlled triaxial apparatus for testing unsaturated soils. Geotechnical Testing Journal, 34(5):424-432. [doi:10.1520/GTJ103586]

Vanapalli, S.K., Fredlund, D.G., Pufahl, D.E., 1999. The influence of soil structure and stress history on the soil-water characteristics of a compacted till. Géotechnique, 49(2):143-159. [doi:10.1680/geot.1999.49.2.143]

Villar, M.V., Lloret, A., 2004. Influence of temperature on the hydro-mechanical behaviour of a compacted bentonite. Applied Clay Science, 26(1-4):337-350. [doi:10.1016/j. clay.2003.12.026]
Wheeler, S.J., Sharma, R.S., Buisson, M.S.R., 2003. Coupling of hydraulic hysteresis and stress-strain behaviour in unsaturated soils. Géotechnique, 53(1):41-54. [doi:10. 1680/geot.2003.53.1.41]

Yao, Y.P., Zhou, A.N., 2013. Non-isothermal unified hardening model: a thermo-elasto-plastic model for clays. Géotechnique, 63(15):1328-1345. [doi:10.1680/geot.13. P.035]

Zhou, A.N., Sheng, D., Carter, J.P., 2012. Modelling the effect of initial density on soil-water characteristic curves. Géotechnique, 62(8):669-680. [doi:10.1680/geot.10.P. 120]

Zhou, A.N., Sheng, D.C., Li, J., 2014. Modelling water retention and volume change behaviours of unsaturated soils in non-isothermal conditions. Computers and Geotechnics, 55(1):1-13. [doi:10.1016/j.compgeo.2013.07.011]

Zhou, J., Yu, J., 2005. Influences affecting the soil-water characteristic curve. Journal of Zhejiang UniversitySCIENCE, 6A(8):797-804. [doi:10.1631/jzus.2005. A0797]

\section{中文概要：}

本文题目: 一种测试不同温度下非饱和土土一水特征曲线的试验装置

A new triaxial apparatus for testing soil water retention curves of unsaturated soils under different temperatures

研究目的: 研制一种试验装置, 以实现对非饱和土土一水特征曲线温度效应的有效测试。

创新要点: 1. 研制了一种温控非饱和土三轴试验装置, 包括加载系统、吸力控制系统和温度控制系统; 2. 利用研制的温控非饱和土三轴试验装置, 对不同温度 $\left(25,40\right.$ 和 $\left.60^{\circ} \mathrm{C}\right)$ 以及不同应力 $(40$, 100 和 $200 \mathrm{kPa}$ ) 条件下的非饱和土土一水特征曲线进行了试验测定。

研究方法: 1. 总结分析已有的温控三轴仪所采用的加热方式的优缺点, 提出环向加热压力室内水体的方 法; 2. 基于 GDS 非饱和土三轴仪, 研制可实现温度控制功能的温控非饱和土三轴仪（图 1、 $2)$; 3. 开展不同温度及不同应力条件下非饱和土土一水特征曲线的试验研究。

重要结论: 1. 所研制的温控非饱和土三轴仪的实用效果得到验证; 2. 温度的升高将引起非饱和土持水性 能的降低。 